\title{
ROLE OF SEED PRIMING AND SPRAYING SOME BIO AND CHEMICAL SUBSTANCES IN RAISING RICE SALINITY TOLERANCE AND PRODUCTIVITY
}

\author{
Amira M. Okasha \\ Rice Research Department, Field Crops Research Institute, ARC, Sakha, Kafr elsheikh, \\ Egypt \\ E-mail address: dramira74@yahoo.com
}

Received: Mar. 13, 2018

Accepted: Apr. 18,2018

\begin{abstract}
The present investigation was carried out in 2015 and 2016 seasons at the experimental Farm of El-Sirw Agriculture at Research Station, Damietta province and lab of Rice Research and Training Center, Sakha, kafr-elsheikh province, Egypt. The objective of this study was to examine the effectiveness of seed priming and foliar spray thoric with solutions of some substances; salicylic acid (SA) $250 \mathrm{ppm}$, yeast (Saccharomyces cervisia) $2 \mathrm{~kg} / \mathrm{fed}$, and the extraction of bacteria (Aizosprillium spp) $2 \%$ conc. at different growth stages (mid tillering, panicle initiation and booting stages) on the performance of three rice varieties viz; Giza177, Giza 179 and Egyptian hybrid one (EHR1) under saline soil conditions. An experiment was performed in spilt plot design with four replications. The tested rice varieties were distributed in the main plots while, the sub plots were devoted to the substances treatments. The salinity levels of experimental site were 7.0 and $7.3 \mathrm{dSm}^{-1}$ in 2015 and 2016 seasons, respectively. The artificial salinity level in Lab experiment was $7.0 \mathrm{dSm}^{-1}$. Significant difference in the performance of tested rice varieties was found in both seasons under Lab and field conditions. Under Lab experiment, Giza177 produced the highest values of germination characters; seed germination, germination energy, final germination and vigor index. Germination characteristics were positively improved owing to seed soaked in Aizosprillium without significant difference with salicylic acid compared to control (untreated one). Under field conditions, Egyptian hybrid rice one produced the highest values of growth parameters, most of yield attributes and grain yield. The tested substances enhanced all studied characters compared with control treatment. The impact of salicylic acid either foliar spray or soaking was superior compared with other treatments for the most studied characters and grain yield followed by bacteria foliar spray and bacteria soaking. Yeast treatments came in the last order. It could be concluded that, rice seed soaking or plant foliar spray with extraction of salicylic acid or bacteria more effective than yeast and improved growth and yield of rice under salt stress.
\end{abstract}

Key words: Rice, salicylic acid, Aizosprillium, yeast, seed soaking, saline soil

\section{INTRODUCTION}

Salinity is one of the adverse factors which can reduce germination and productivity of crops worldwide. Soil salinization affects plants by several ways inducing water deficit in attributed to soils by reducing the osmotic potential of soil solutes which makes it difficult for roots to take up water from the soil
(Sairam et al., 2002). Egypt has long suffering from issues agriculture sector relating to mismanagement of agricultural lands (SIT 2010). so, there is an urgent need to increase agricultural land management for meeting the increasing populations by increasing crop productivity specially rice which is considered one of the most important 
cereal crop, thus. affected by soil salinity, (Karan et al., 2012). Rice responds to salt stress in the same manner as other glycophytes by using a number of strategies which include minimizing influx, maintaining efflux, and translocation and compartmentalizing potentially toxic ions such as $\mathrm{Na}^{+}$and $\mathrm{Cl}^{-}$ ( Anil et al., 2007). So, it has become necessary to use some materials to encourage growth processes in plants and reduce the detrimental effects of salinity by stimulating growth. Salicylic acid (SA), an endogenous growth regulator of phenolic nature, influences many physiological processes such as; seed germination (Cutt \& Klessing 1992), ion permeability (Barkosky \& Einhelling 1993), photosynthesis and plant growth rate (Rafique et al., 2011). Salicylic acid also prevents the damaging action of various stress factors in many plant species (Afzal et al., 2005). Bio-fertilizers, in strict sense, are not fertilizers that directly give nutrition to rice plants. Azospirillum, is one of the best-studied plant growth-promoting, Aizosprillium can utilize atmospheric nitrogen and contribute to plant nitrogen nutrition, Azospirillum can increase the nutrient uptake inside plant, and improve the balance of the root environment through protection against pathogens and equilibrate nutrient flow into the soil, resulted in enhancing crop yield. It also has ability to produce phytohormones, mainly auxins (indole-3-acetic acid), (Bashan and De-Bashan 2010; Babalola and Glick 2012 and Glick 2014) yeast is a cost-effective bio fertilizer that improves not only plant nutrition but also plant vigor during the early growth phase (Lonhienne et al 2015). Yeast (Saccharomyces cervisia) is rich phytohormones (cytokinins), vitamins, amino acids, enzymes and minerals, and contains tryptophane which is the precursor of indol acetic acid which promotes plant growth. (Darweesh et al., 2003).

The objective of the current study is improvising salinity withstanding and enhancing productivity of some rice varieties by seed priming, and plant foliar spray using some bio and chemical substances under salt stress conditions.

\section{MATERIALS AND METHODS \\ Laboratory experiments}

Laboratory experiments were conducted at laboratory of salinity at Rice Research and Training Center, Kafrelshiekh province, Egypt on $1^{\text {st }}$ May and $30^{\text {th }}$ April in 2015 and 2016 rice season respectively. The germination test was conducted using the Petri dish method in split plot design. Two pieces of blotting papers were used in each Petri dish as a substrate. Seed of Giza177, Giza 179 and Egyptian hybrid one cultivars were soaked at the solution of salicylic acid, bacteria and yeast for 48 hour, then twenty five seeds of tested rice varieties were placed in medium size Petri dish. Each treatment was replicated four times. The salinity irrigation water was used at the concentration of $7 \mathrm{dSm}^{-1}$ used for germination of seeds, and tap water was used in control treatment. The petri dishes were daily monitored.

Germination rate was computed using the formula proposed by (IRRI 2011):

Germination rate $=$ (Number of seed that geminated/ Number of seed on the tray) *100

Germination energy $=$ Percentage of seeds germinated at $72 \mathrm{~h}$ (Bam et al., 2006).

Final germination percentage (FGP\%) using the formula proposed by (Kandil et al., 2012)

FGP\%= Number of final germinated seed/Total number of seed tested

Vigor Index $=$ number of germinated seeds I days of first count $+\ldots . .+$ number of germinated seeds/days at final count (Islam et al., 2012) 


\section{Field experiment}

The field experiments were conducted at the Farm of El-Sirw Agricultural Research Station, Damietta Governorate, Egypt in the two seasons of 2015 and 2016, to observe the efficiency of seed soaking and foliar spray of salicylic acid at the rate of $250 \mathrm{ppm}$ and bacteria (Aizosprillium) extraction $2 \%$ and yeast extract at the rate of $2 \mathrm{~kg} / \mathrm{fed}$ at various rice growth stages (mid tillering, panicle initiation and booting stages) on growth and yield of three varying rice varieties viz; Giza 177, Giza179 and EHR1. The previous crop was Egyptian clover in the two seasons. Representative soil samples were taken from each site at the depth of $0-30 \mathrm{~cm}$ from the soil surface. Samples were chemically analyzed according to (Black et al 1965). Results of chemical analysis of both seasons are listed in Table 1.

The experimental soil was fertilized with phosphorus in form of calcium superphosphate $\left(15.5 \% \mathrm{P}_{2} \mathrm{O}_{5}\right)$ at the rate of $53.6 \mathrm{~kg} \mathrm{P}_{2} \mathrm{O}_{5} \mathrm{ha}^{-1}$ and potassium sulphate at the rate of $\mathrm{kg} 50 \mathrm{k}_{2} \mathrm{O} \mathrm{ha}^{-1}$ according to saline soil recommendations. The experimental design was split plot design with four replications. The main plots were assigned to rice varieties, while the subplots were assigned to the different substances. Foliar applications were carried out at three rice growth stages, i.e. mid tillering (MT), panicle initiation (PI) and booting (BT). The plot area was $10 \mathrm{~m}^{2}(5 \times 2 \mathrm{~m})$. Seedlings, aged 30 days, were transplanted at the plant spacing of $20 \times 20 \mathrm{~cm}$, apart. Nitrogen in the form of urea at the rate of $165 \mathrm{~kg} \mathrm{~N} \mathrm{ha}^{-1}$ was applied in four splits, 15, 30 and 45 days after transplanting as well as mid booting stage as recommended for salt affected soil.

Seed at a rate of $140 \mathrm{~kg} \mathrm{ha}^{-1}$ were soaked in water for $48 \mathrm{hr}$ this for foliar spray with extract of bacteria, salicylic acid and yeast. The same rate of seeds were soaked in extract of bacteria, salicylic acid and yeast, then incubated for $24 \mathrm{hr}$ regarding seed priming treatments. All other agronomic practices were followed as recommended package of rice under saline soil during the growing season.

\section{Measurements of root and shoot lengths of seedlings}

Randomly selected ten seedlings were randomly taken from nursery (26 days after sowing) and transferred to lab, then root and shoot length of seedling were measure.

At heading stage, plants of five hills were taken randomly from each plot to estimate dry matter ${ }^{-1}$. Ten leaves were randomly taken to determine leaf area, chlorophyll content and sodium $\left(\mathrm{Na}^{+}\right)$, potassium $\left(\mathrm{K}^{+}\right)$and $\mathrm{Na}^{+} / \mathrm{K}^{+}$ratio. Leaf area of plant samples were measured by Portable Area Meter (Model LI- 3000A). Total chlorophyll content was determined in ten flag leaf using chlorophyll meter (Model-SPAD502) Minolta Camera Co. Ltd., Japan. Ten leaves were randomly taken from each plot, dried and ground to estimate $\mathrm{Na}, \mathrm{K}$ and $\mathrm{Na} / \mathrm{K}$ ratio using Flame Photometer according to (Chapman and Pratt 1978).

Table (1): Chemical of the experimental soil $(0-30 \mathrm{~cm}$ depth)

\begin{tabular}{|c|c|c|c|c|c|c|c|c|c|c|c|}
\hline \multirow[t]{2}{*}{ season } & $E_{e}$ & \multirow[t]{2}{*}{ pH } & $\mathrm{Ca}^{+2}+\mathrm{Mg}^{+2}$ & $\mathrm{Na}^{+1}$ & $\mathrm{~K}^{+1}$ & $\mathrm{HCo}^{-3}$ & $\mathrm{Cl}$ & $\mathrm{So}_{4}{ }^{+2}$ & $\mathbf{N}$ & $\mathbf{P}$ & $\mathrm{K}$ \\
\hline & dS. $m^{-1}$ & & \multicolumn{6}{|c|}{ meq. $I^{-1}$} & \multicolumn{3}{|c|}{ ppm } \\
\hline 2015 & 7.00 & 8.3 & 20.0 & 50.0 & 0.31 & 8.51 & 30.5 & 31.0 & 30 & 12 & 287 \\
\hline 2016 & 7.3 & 8.4 & 21.1 & 52.5 & 0.31 & 8.88 & 31.6 & 32.2 & 31 & 12.5 & 309 \\
\hline
\end{tabular}


At harvest, plant height, panicle length, tiller number/hill, panicle number/hill were estimated. Ten panicles were randomly collected to estimate the panicle weight, panicle length; number of filled grains and unfilled grains panicle ${ }^{-1}$ and 1000-grain weight. The six inner rows of each plot were harvested, dried, threshed, and the grain and straw yields were determined based on the moisture content of $14 \%$. The yield was converted to grain yield $\mathrm{ha}^{-1}$. The obtained data were subjected to analysis of variance according to (Gomez and Gomez 1984). Treatment means were compared by Duncan's Multiple Range Test (Duncan 1955). All statistical analyses were performed using analysis of variance technique by means of "COTATC" computer software package.

\section{RESULTS AND DISCUSSION}

\section{Some Germination and seedling characters}

\subsection{Rice varieties performance}

The results showed that tested rice varieties had highly significant effects on seed germination, germination energy, final germination and vigor index in both seasons (Table 2). Giza177 exhibited the highest rates of germinated\%, as well the highest percentage of germination energy, final germination and vigor index in both season followed by Egyptian hybrid one. Giza179 came in the last rank in both seasons. The differences between rice varieties in seed germination characters and seedling vigor may be due to variation in hull, ecotype, pericarp and endosperm characters (kouio 2003 and Lee et al., 2002). Furthermore, the 1000-grain weight of Giza 177 is heaviest indicating more starch resulted in fast germination and improved seedling despite its salt sensitively.

Table (2): Seed germination characteristics and vigor index of some rice varieties as affected by soaking in some substances under saline soil

\begin{tabular}{|c|c|c|c|c|c|c|c|c|}
\hline \multirow[t]{2}{*}{ Factor } & \multicolumn{2}{|c|}{ Germination\% } & \multicolumn{2}{|c|}{$\begin{array}{c}\text { Germination } \\
\text { energy } \%\end{array}$} & \multicolumn{2}{|c|}{$\begin{array}{c}\text { Final } \\
\text { germination\% }\end{array}$} & \multicolumn{2}{|c|}{ Vigor index } \\
\hline & 2015 & 2016 & 2015 & 2016 & 2015 & 2016 & 2015 & 2016 \\
\hline \multicolumn{9}{|l|}{ Varieties } \\
\hline Giza177 & $87.75 a$ & $86.58 a$ & $91.33 a$ & $87.03 a$ & $95.33 a$ & $94.66 a$ & $10.69 a$ & $10.32 a$ \\
\hline Giza179 & $71.58 \mathrm{c}$ & $69.41 \mathrm{c}$ & $80.33 b$ & $79.93 b$ & $84.33 c$ & $82.00 \mathrm{c}$ & $8.15 b$ & $7.63 \mathrm{c}$ \\
\hline EHR1 & $75.50 \mathrm{~b}$ & $78.41 b$ & $79.33 b$ & $72.84 \mathrm{c}$ & $88.00 \mathrm{~b}$ & $88.33 b$ & $8.67 b$ & $9.08 b$ \\
\hline F test & * & * & $* *$ & $* *$ & $* *$ & $* *$ & $* *$ & ** \\
\hline \multicolumn{9}{|l|}{ Substances } \\
\hline Control & $76.2 b$ & $73.88 b$ & $80.44 b$ & $78.19 b$ & $86.22 b$ & $82.66 \mathrm{~b}$ & $8.98 b$ & $8.51 b$ \\
\hline Salicylic soaking & $84.1 \mathrm{a}$ & $83.00 a$ & $88.00 a$ & 79.83ab & 91.55ab & $91.55 a$ & $10.39 a$ & $9.94 a$ \\
\hline Bacteria soaking & $83.66 a$ & $82.55 a$ & $90.22 a$ & $84.36 a$ & $92.88 a$ & $92.88 a$ & $9.94 a$ & $9.56 \mathrm{a}$ \\
\hline Yeast soaking & $69.11 \mathrm{c}$ & 73.11b & $76.00 \mathrm{~b}$ & $77.36 \mathrm{~b}$ & $86.22 b$ & $86.22 b$ & $7.38 \mathrm{c}$ & $8.03 b$ \\
\hline F test & $* \star$ & $* *$ & ** & ** & ** & ** & $* *$ & ** \\
\hline Interaction & NS & NS & NS & NS & NS & NS & NS & NS \\
\hline
\end{tabular}

*, ** and Ns indicate $P<0.05, P<0.01$ and not significant, respectively. Means of each factor designated by the same latter are not significantly different at $5 \%$ level using Duncan's Multiple Range Test. 


\subsection{Substances effect}

The seed priming treatments including bio and chemical substances significantly varied in their effect on rice germination characters. Generally, seed priming improved germination characteristics. It was observed that couple treatments of SA and bacteria were more efficient in improving germination criterion than yeast treatment. On the other hand, the yeast did not show reasonable improvement in rice seed germination since it did not differ significantly than control treatment in the most of studied germination traits or less than control in some of them. Salt stress decreases seed germination characters this may be to declining water uptake by endosperm which cause decrease in protease, amylase activity and RNA content, in addition to ionic imbalance (sodium $\left(\mathrm{Na}^{+}\right.$) and chloride ( $\left.\mathrm{Cl}^{-}\right)$ions (Hosseini et al., 2003). Salicylic acid and bacteria seed priming might mitigate the adverse action of various stresses on seed germination by increasing the releasing of alpha amylase enzyme which accelerates starch decomposition to mono saccharide reflected on rice germination (Afzal et al., 2005; Iqbal and Ashraf, 2010). Aizosprillium has been suggested as plant-growth promoting bacteria (Bashan and Holguin 1998) which led to enhancement of seed germination characters.

\section{Seedling characters}

\subsection{Rice varieties performance}

Data analysis variance referred that the three tested rice varieties greatly varied in their germination criteria in both seasons (Table 3). Egyptian hybrid one significantly produced the tallest shoots and roots of seedling without significant difference with Giza179 in seedling root length in both seasons. Shoot and root ratio was inconstant, Giza177 produced the highest ratio in the first season and Giza 179 produced the highest value in the second season. Despite rice is sensitive to salinity, EHR1 rice variety had the ability to tolerant salinity stress, may be due to increment of antioxidant enzymes and proline which are proposed to be important in plant stress. Similar were obtained by (Zayed et al., 2017).

\subsection{Substances effect}

Data in Table 3 show that seedling shoot and root length and shoot/root ratio of rice were significantly affected by soaking in bio and chemical substances compared with control treatment in both seasons. Soaking in salicylic acid improved rice seedling shoot length in both seasons without significant difference with soaking in bacteria in the second season. Soaking in bacteria enhanced seedling root length in both seasons without significant difference with salicylic soaking in the second season. Shoot/root ratio was increased by salicylic acid in the first season as well, bacteria and yeast in the second season. The increase in root growth due to SA maintaining the hormonal balance (IAA and cytokine levels) in the plant tissues, which enhance cell division (Sakhabutdinova et al., 2003) and cell replication in root tips, and thus increased root growth. Bacteria enhancing shoot and root length may be due to the ability of bacteria to active auxins and gibberellins, both of them are the key factor in improving rice seedling length (Basra et al., 2006).

\subsection{Interaction effect}

The interaction between rice varieties and substances had a significant effect on seedling shoot and root lengths in both seasons (Table 4). Seedling shoot and root length of rice varieties soaked at different substances was increased compared with control treatment in both 
seasons. The tallest seedlings were obtained with Egyptian hybrid one when soaked at salicylic acid in the first season and bacteria in the second season. Egyptian hybrid one soaked at bacteria produced the tallest roots in both seasons without significant differences with salicylic in the second season. Metabolites which are produced by SA and bacteria influence the early stage of plant development through the enhancement of root length of rice varieties. In addition, Azospirillum strains produce various Lectins which induce several signaling systems in plant roots as part of the recognition in the initial stages of development of plant (Trutneva et al., 2014).

Table 3: Rice seedling shoot and root length as affected by some substances under saline soil

\begin{tabular}{|c|c|c|c|c|c|c|}
\hline \multirow[t]{2}{*}{ Factor } & \multicolumn{2}{|c|}{$\begin{array}{c}\text { Seedling shoot } \\
\text { length }\end{array}$} & \multicolumn{2}{|c|}{ Seedling root length } & \multicolumn{2}{|c|}{ Shoot/ root ratio } \\
\hline & 2015 & 2016 & 2015 & 2016 & 2015 & 2016 \\
\hline \multicolumn{7}{|l|}{ Varieties } \\
\hline Giza177 & $18.58 b$ & $17.95 b$ & $10.09 c$ & $11.04 b$ & $1.84 a$ & $1.62 \mathrm{~b}$ \\
\hline Giza179 & $19.28 a$ & $19.09 \mathrm{ab}$ & $11.37 b$ & $10.89 b$ & $1.69 \mathrm{~b}$ & $1.75 a$ \\
\hline EHR1 & $19.64 a$ & $19.58 \mathrm{a}$ & $13.03 a$ & $13.70 \mathrm{a}$ & $1.50 \mathrm{c}$ & $1.42 \mathrm{C}$ \\
\hline F test & ** & * & ** & * & ** & $\star *$ \\
\hline \multicolumn{7}{|l|}{ Substances } \\
\hline Control & $16.22 d$ & $16.44 \mathrm{c}$ & $10.21 d$ & 10.70b & $1.68 b$ & $1.53 b$ \\
\hline Salicylic soaking & $21.58 \mathrm{a}$ & $19.85 a$ & $11.88 b$ & $12.77 a$ & $1.81 a$ & $1.55 b$ \\
\hline Bacteria soaking & $19.61 b$ & $20.45 a$ & $12.92 \mathrm{a}$ & $12.71 \mathrm{a}$ & $1.51 \mathrm{c}$ & $1.60 \mathrm{a}$ \\
\hline Yeast soaking & $19.2 \mathrm{c}$ & $18.75 b$ & $10.94 \mathrm{c}$ & $11.33 b$ & $1.66 \mathrm{~b}$ & $1.65 a$ \\
\hline F test & ** & ** & 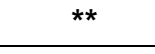 & ** & $* *$ & $\star \star$ \\
\hline Interaction & ** & ** & ** & ** & NS & NS \\
\hline
\end{tabular}

*, ** and NS indicate $P<0.05, P<0.01$ and not significant, respectively. Means of each factor designated by the same latter are not significantly different at $5 \%$ level using Duncan's Multiple Range Test.

Table 4: Shoot and root length $(\mathrm{cm})$ as affected by interaction between rice varieties and different substances

\begin{tabular}{|l|c|c|c|c|c|c|}
\hline \multirow{2}{*}{ Substance } & \multicolumn{5}{|c|}{ Shoot length(cm) } & \multicolumn{3}{c|}{ Root length (cm) } \\
\cline { 2 - 7 } & \multicolumn{7}{|c|}{2015} \\
\cline { 2 - 7 } & Giza 177 & Giza 179 & EHRI & Giza 177 & Giza 179 & EHRI \\
\hline Control & $15.6 \mathrm{e}$ & $16.13 \mathrm{~d}$ & $16.93 \mathrm{~d}$ & $9.20 \mathrm{e}$ & $10.43 \mathrm{e}$ & $11.00 \mathrm{~d}$ \\
\hline Salicylic soaking & $19.36 \mathrm{c}$ & $22.0 \mathrm{~b}$ & $23.4 \mathrm{a}$ & $9.30 \mathrm{e}$ & $11.93 \mathrm{~cd}$ & $14.40 \mathrm{~b}$ \\
\hline Bacteria soaking & $20.2 \mathrm{c}$ & $19.20 \mathrm{c}$ & $19.43 \mathrm{c}$ & $11.66 \mathrm{~cd}$ & $11.56 \mathrm{~cd}$ & $15.66 \mathrm{a}$ \\
\hline Yeast soaking & $19.0 \mathrm{c}$ & $19.8 \mathrm{c}$ & $18.8 \mathrm{c}$ & $10.20 \mathrm{e}$ & $11.56 \mathrm{c}$ & $11.06 \mathrm{~d}$ \\
\hline \multicolumn{7}{|c|}{2016} \\
\hline Control & $15.60 \mathrm{e}$ & $16.8 \mathrm{de}$ & $16.93 \mathrm{de}$ & $10.56 \mathrm{c}$ & $10.53 \mathrm{c}$ & $11.00 \mathrm{c}$ \\
\hline Salicylic soaking & $19.3 \mathrm{bc}$ & $21.00 \mathrm{~b}$ & $19.20 \mathrm{bc}$ & $11.26 \mathrm{bc}$ & $11.33 \mathrm{bc}$ & $15.73 \mathrm{a}$ \\
\hline Bacteria soaking & $18.5 \mathrm{~cd}$ & $19.43 \mathrm{bc}$ & $23.40 \mathrm{a}$ & $11.43 \mathrm{bc}$ & $11.66 \mathrm{bc}$ & $15.00 \mathrm{a}$ \\
\hline Yeast soaking & $18.3 \mathrm{~cd}$ & $19.13 \mathrm{bc}$ & $18.80 \mathrm{c}$ & $10.90 \mathrm{bc}$ & $10.04 \mathrm{c}$ & $13.06 \mathrm{~b}$ \\
\hline
\end{tabular}

*and** indicate $P<0.05$ and $P<0.01$, respectively. Means of each factor designated by the same latter are not significantly different at 5\% level using Duncan's Multiple Range Test. 
3. Some minerals content $\left(\mathrm{Na}^{+}, \mathrm{K}^{+}\right.$ and $\mathrm{Na} / \mathrm{K}$ ratio) in rice leaves

\section{1: Rice varieties performance}

Rice varieties markedly varied in their sodium $\left(\mathrm{Na}^{+}\right)$, potassium $\left(\mathrm{K}^{+}\right)$and sodium potassium ratio $(\mathrm{Na} / \mathrm{K})$ in both seasons (Table 5). The highest values of Na leaf content and $\mathrm{Na} / \mathrm{K}$ ratio were recorded by Giza 177 rice variety. Meanwhile, the lowest values was observed by Egyptian hybrid one without significant differences with Giza 179 in both seasons. Egyptian hybrid one produced the highest values of $\mathrm{K}^{+}$content without significant difference with Giza 179 while, Giza 177 gave the lowest values of $\mathrm{K}^{+}$content in both seasons. The variation among rice varieties tested rice varieties are mainly due to their ability variable in ion selectivity. Giza 179 and EHR1 showed high ion selectivity that enable them to uptake more potassium against than sodium, which resulted in low $\mathrm{Na}^{+} / \mathrm{K}^{+}$ ratio. Vice versa, Giza 177 showed low ion selectivity producing high $\mathrm{Na}^{+} / \mathrm{K}^{+}$ ratio confirming its salinity sensitivity. The current results confirmed that Giza179 and EHR1 are salt tolerant (Zayed et al., 2017). Furthermore, there results refer that the Giza 179 and EHR1 had the gene related to ion selectivity in the terms of salt gene.

\subsection{Substances effect}

The potassium\%, sodium $\%$ and $\mathrm{Na}^{+} / \mathrm{K}^{+}$ratio of rice were significantly affected by different bio and chemical substances in both seasons. The tested substances significantly reduced $\mathrm{Na}^{+} \%$ and $\mathrm{Na}^{+} / \mathrm{K}^{+}$ratio of rice compared with control treatment. On the other hand, $\mathrm{K}^{+}$ leaf content increased by tested substances.

Table (5): Sodium\%, potassium\% and sodium potassium ratio of some rice varieties as affected by some substances under saline soil in 2015 and 2016 seasons.

\begin{tabular}{|c|c|c|c|c|c|c|}
\hline \multirow[t]{2}{*}{ Treatment } & \multicolumn{2}{|c|}{$\mathrm{Na}^{+} \%$} & \multicolumn{2}{|c|}{$\mathrm{K}^{+} \%$} & \multicolumn{2}{|c|}{$\mathrm{Na}^{+} / \mathrm{K}^{+}$} \\
\hline & 2015 & 2016 & 2015 & 2016 & 2015 & 2016 \\
\hline \multicolumn{7}{|l|}{ Varieties } \\
\hline Giza177 & $1.93 a$ & $2.10 a$ & $0.85 c$ & $0.88 c$ & $2.27 a$ & $2.38 a$ \\
\hline Giza179 & $1.21 b$ & $1.24 b$ & $2.30 \mathrm{ab}$ & $2.36 a b$ & $0.53 b$ & $0.53 b$ \\
\hline EHR1 & $1.20 \mathrm{~b}$ & $1.22 b$ & $2.70 a$ & $2.69 a$ & $0.44 b c$ & $0.44 b c$ \\
\hline F test & * & * & ** & $* *$ & $* *$ & ** \\
\hline \multicolumn{7}{|l|}{ Substances } \\
\hline Control & $1.97 a$ & $2.05 a$ & $1.45 \mathrm{ef}$ & $1.46 \mathrm{de}$ & $1.36 a$ & $1.40 a$ \\
\hline Salicylic soaking & $1.05 \mathrm{e}$ & $1.08 \mathrm{e}$ & $2.49 b$ & $2.27 b$ & $0.42 d$ & $0.48 d$ \\
\hline Bactria soaking & $1.31 \mathrm{~d}$ & $1.35 d$ & $1.58 \mathrm{e}$ & $1.68 d$ & $0.83 c$ & $0.80 \mathrm{c}$ \\
\hline Yeast soaking & $1.75 a b$ & $1.85 a b$ & $1.56 \mathrm{e}$ & $1.63 d$ & $1.12 b$ & $1.14 b$ \\
\hline Salicylic spray & $1.03 e$ & $1.15 \mathrm{e}$ & $2.83 a$ & 2.91a & $0.36 \mathrm{de}$ & $0.40 \mathrm{de}$ \\
\hline Yeast spray & $1.43 \mathrm{~cd}$ & $1.52 \mathrm{~cd}$ & $1.78 \mathrm{~d}$ & $1.93 \mathrm{c}$ & $0.80 c$ & $0.79 c$ \\
\hline Bacteria spray & $1.59 \mathrm{c}$ & $1.63 c$ & $1.99 \mathrm{c}$ & $1.93 \mathrm{c}$ & $0.79 c$ & $0.85 c$ \\
\hline F test & * & * & $* *$ & $* *$ & $* *$ & $* *$ \\
\hline Interaction & Ns & Ns & Ns & Ns & Ns & Ns \\
\hline
\end{tabular}

*, ** and Ns indicate $P<0.05, P<0.01$ and not significant, respectively. Means of each factor designated by the same latter are not significantly different at 5\% level using Duncan's Multiple Range Test. 
The highest value of $\mathrm{K} \%$ was obtained by salicylic foliar spray compared with other treatments in both seasons. The tested bio or chemical substances might be beefed up the $\mathrm{K}^{+}$anti-porters on cell membrane formation and uptake more potassium against sodium inducing low $\mathrm{Na}^{+} / \mathrm{K}^{+}$ratio. Moreover, applying the tested substances seem to be effective to enable rice plants to discarded $\mathrm{Na}^{+}$from cytoplasm to vacuole and old leaves. Salt stress results in deterioration of plasma membrane so, application of SA acid may be mitigate this injury effect and maintain membrane stabilization which increases the uptake of nutrients (Parizi et al., 2011). Sodium $\left(\mathrm{Na}^{+}\right)$and $\mathrm{K}^{+}$homeostasis inside the cell was found to be an important for the activity of several cytosolic enzymes and for the reservation of membrane potential and cell volume regulation (Hussein et al., 2007). Salicylic reduced $\mathrm{Na} \%$ and increases $\mathrm{K} \%$, causing a signification reduction in $\mathrm{Na}^{+} / \mathrm{K}^{+}$ratios (El-Hedek 2013).

\section{Some growth characters}

\subsection{Rice varieties performance}

Data in Table 6 indicated that leaf area index (LAI), dry matter ${ }^{-1}$ and chlorophyll content of rice varieties significantly varied in both seasons. Egyptian hybrid one surpassed other tested rice varieties. Giza 179 rice variety came in the second rank after EHR1 while, Giza177 came in the last order with respect to above mentioned traits. The superiority of EHR1 may be due to its affinity to increase antioxidant enzymes and proline which are important to protect the plants from the salinity injury (Zayed et al., 2007 and 2017). The heterosis of hybrid rice is higher than of that inbred rice, so the hybrids produce large leaf area and high dry matter (Zayed et al., 2017);

Table (6): Leaf area index (LAI), dry matter accumulation, chlorophyll content, of some rice varieties as affected by some substances under saline soil

\begin{tabular}{|l|c|c|c|c|c|c|}
\hline \multirow{2}{*}{ Treatment } & \multicolumn{3}{|c|}{ LAI } & \multicolumn{2}{c|}{ dry matter g/hill } & \multicolumn{2}{l|}{ chlorophyll (SPAD value) } \\
\cline { 2 - 7 } & 2015 & 2016 & 2015 & 2016 & 2015 & 2016 \\
\hline Varieties & \multicolumn{7}{|c|}{} \\
\hline Giza177 & $3.98 \mathrm{c}$ & $3.09 \mathrm{c}$ & $32.47 \mathrm{c}$ & $31.56 \mathrm{c}$ & $0.59 \mathrm{c}$ & $0.53 \mathrm{c}$ \\
\hline Giza179 & $5.04 \mathrm{~b}$ & $4.42 \mathrm{~b}$ & $41.76 \mathrm{~b}$ & $40.66 \mathrm{~b}$ & $0.63 \mathrm{~b}$ & $0.60 \mathrm{~b}$ \\
\hline EHR1 & $5.99 \mathrm{a}$ & $5.35 \mathrm{a}$ & $51.15 \mathrm{a}$ & $49.91 \mathrm{a}$ & $0.71 \mathrm{a}$ & $0.69 \mathrm{a}$ \\
\hline F test & $* *$ & $* *$ & $* *$ & $* *$ & $* *$ & $* *$ \\
\hline Substance & \multicolumn{7}{|c|}{} \\
\hline Control & $4.29 \mathrm{e}$ & $3.77 \mathrm{f}$ & $33.92 \mathrm{e}$ & $32.06 \mathrm{f}$ & $0.55 \mathrm{e}$ & $0.52 \mathrm{f}$ \\
\hline Salicylic soaking & $5.26 \mathrm{~b}$ & $4.63 \mathrm{~b}$ & $45.55 \mathrm{~b}$ & $43.69 \mathrm{c}$ & $0.67 \mathrm{~b}$ & $0.64 \mathrm{~b}$ \\
\hline Bacteria soaking & $4.56 \mathrm{~d}$ & $4.21 \mathrm{~d}$ & $36.40 \mathrm{~d}$ & $42.20 \mathrm{~d}$ & $0.67 \mathrm{~b}$ & $0.63 \mathrm{c}$ \\
\hline Yeast soaking & $4.89 \mathrm{c}$ & $4.36 \mathrm{c}$ & $44.69 \mathrm{~b}$ & $42.83 \mathrm{~d}$ & $0.63 \mathrm{c}$ & $0.58 \mathrm{e}$ \\
\hline Salicylic spray & $5.60 \mathrm{a}$ & $4.82 \mathrm{a}$ & $47.91 \mathrm{a}$ & $46.23 \mathrm{a}$ & $0.71 \mathrm{a}$ & $0.65 \mathrm{ab}$ \\
\hline Yeast spray & $5.38 \mathrm{~b}$ & $4.66 \mathrm{~b}$ & $42.83 \mathrm{c}$ & $40.97 \mathrm{e}$ & $0.64 \mathrm{c}$ & $0.59 \mathrm{~d}$ \\
\hline Bacteria spray & $5.71 \mathrm{a}$ & $4.18 \mathrm{e}$ & $47.48 \mathrm{a}$ & $44.95 \mathrm{~b}$ & $0.72 \mathrm{a}$ & $0.66 \mathrm{a}$ \\
\hline F test & $* *$ & $* *$ & $*$ & $* *$ & $* *$ & $* *$ \\
\hline
\end{tabular}

*and** indicate $P<0.05$ and $P<0.01$, respectively. Means of each factor designated by the same latter are not significantly different at $5 \%$ level using Duncan's Multiple Range Test. 


\subsection{Substances effect}

Rice plants treated with substances resulted in a significant increase in leaf area index (LAI), dry matter hill $^{-1}$, chlorophyll content compared with control treatment in the two seasons.

A significant increment in leaf area index and dry matter was obtained by foliar spray with salicylic acid without significant difference with bacteria in the first season. Moreover, salicylic acid foliar spray without significant difference with bacteria foliar spray produced the highest value of chlorophyll content in both seasons. The beneficial influences of SA might be due to it is role as endogenous growth regulator of phenolic nature influences many physiological processes ion permeability photosynthesis and plant growth rate (Rafique et al., 2011) Salicylic acid also prevents the damaging action of various stress factors in many plant species (Afzal et al., 2005). These results are in agreement with those obtained by (Mohamed et al., 2015).

\subsection{The interaction effect}

The interaction between rice varieties and varying substances shows a significant effect on leaf area index in the second season and dry matter in both seasons (Tables 7 and 8). Egyptian hybrid one treated with salicylic either spraying or soaking significantly increased dry matter hill ${ }^{-1}$ without variation with bacteria foliar spray and yeast soaking in both season. Aso EHRI and salicylic foliar spray produced the highest value of leaf area index. Meanwhile, control treatment with all test rice varieties gave the lowest values of leaf area index and dry matter hill $^{-1}$ in both seasons. Giza 177 rice variety and yeast spray produced the lowest values of leaf area index and dry matter ${ }^{-1}$ hill compared with other varieties and other treatments.

Table 7: Leaf area index as affected by interaction between rice varieties and different substances in 2016 season

\begin{tabular}{|l|c|c|c|}
\hline Substance & Giza 177 & Giza 179 & EHR1 \\
\hline Control & $2.53 \mathrm{i}$ & $3.89 \mathrm{f}$ & $4.90 \mathrm{~d}$ \\
\hline Salicylic soaking & $3.28 \mathrm{~h}$ & $4.86 \mathrm{~d}$ & $5.76 \mathrm{~b}$ \\
\hline Bactria soaking & $3.38 \mathrm{~g}$ & $4.33 \mathrm{e}$ & $4.91 \mathrm{~d}$ \\
\hline Yeast soaking & $3.43 \mathrm{fg}$ & $4.38 \mathrm{e}$ & $5.26 \mathrm{c}$ \\
\hline Salicylic spray & $3.00 \mathrm{~h}$ & $5.18 \mathrm{c}$ & $6.28 \mathrm{a}$ \\
\hline Yeast spray & $3.38 \mathrm{~g}$ & $4.88 \mathrm{~d}$ & $5.73 \mathrm{~b}$ \\
\hline Bactria spray & $3.30 \mathrm{fg}$ & $4.12 \mathrm{e}$ & $5.10 \mathrm{~b}$ \\
\hline
\end{tabular}

Table 8: Dry matter accumulation ( $\mathrm{g} / \mathrm{hill}$ ) as affected by interaction between rice varieties and different substances.

\begin{tabular}{|l|l|l|l|c|c|c|}
\hline \multirow{2}{*}{ Substance } & \multicolumn{3}{|c|}{2015} & \multicolumn{3}{c|}{2016} \\
\cline { 2 - 7 } & Giza 177 & Giza 179 & EHR1 & Giza 177 & Giza 179 & EHR1 \\
\hline Control & $26.33 \mathrm{j}$ & $31.43 \mathrm{i}$ & $44.0 f$ & $24.47 \mathrm{j}$ & $29.57 \mathrm{i}$ & $42.14 \mathrm{f}$ \\
\hline salicylic soaking & $\mathbf{3 6 . 3 3 \mathrm { g }}$ & $45.99 \mathrm{ef}$ & $54.33 \mathrm{ab}$ & $34.47 \mathrm{~g}$ & $44.13 \mathrm{ef}$ & $52.47 \mathrm{ab}$ \\
\hline Bacteria soaking & $\mathbf{2 7 . 7 6 \mathrm { j }}$ & $34.99 \mathrm{gh}$ & $46.44 \mathrm{ef}$ & $35.90 \mathrm{~g}$ & $41.13 \mathrm{~h}$ & $49.58 \mathrm{c}$ \\
\hline Yeast soaking & $\mathbf{3 5 . 2 0 \mathrm { gh }}$ & $44.44 \mathrm{f}$ & $54.43 \mathrm{ab}$ & $33.34 \mathrm{gh}$ & $42.58 f$ & $52.57 \mathrm{ab}$ \\
\hline salicylic spray & $\mathbf{3 7 . 4 0 \mathrm { g }}$ & $49.77 \mathrm{~cd}$ & $56.55 \mathrm{a}$ & $36.10 \mathrm{f}$ & $47.91 \mathrm{~cd}$ & $54.69 \mathrm{a}$ \\
\hline Yeast spray & $\mathbf{3 2 . 1 0 \mathrm { hi }}$ & $44.40 \mathrm{f}$ & $51.99 \mathrm{bc}$ & $30.24 \mathrm{hi}$ & $42.54 \mathrm{f}$ & $50.13 \mathrm{bc}$ \\
\hline Bactria spray & $\mathbf{3 7 . 0 0 \mathrm { g }}$ & $48.66 \mathrm{de}$ & $56.77 \mathrm{a}$ & $33.14 \mathrm{gh}$ & $46.80 \mathrm{de}$ & $54.91 \mathrm{a}$ \\
\hline
\end{tabular}




\section{Yield Attribute characters:}

\subsection{Rice varieties performance}

Data presented in Tables 9,11,12,13 and 15 indicated that plant height, tillers number hill ${ }^{-1}$, panicle numbers hill $^{-1}$, panicle length, filled grains, unfilled grains, panicle weight, and 1000 grain weight of rice varied among the tested rice varieties in 2015 and 2016. Egyptian hybrid one confirmed its superiority over other rice varieties and gave the tallest plants, the maximum values of number of tillers and panicles, longest panicle, as well as the tallest panicle and the highest number of filled grains in both seasons. Concerning number of unfiled grains panicle $^{-1}$, the highest numbers of unfilled grains were in favor of Giza177 in the two seasons, while the lowest values of it were produced by Giza 179. EHR1 recorded the heaviest panicles weight in the two seasons of study. On the other hand, the lightest panicles weight was produced by Giza 177 . At the same time, Giza 177 produced the heaviest 1000grain, while the lightest ones were obtained by Giza179. The obtained variation among rice varieties regarding the current parameters might mainly be due to genetic makeup. Similar findings were obtained by Kishk 2006, Alam et al,. 2009 and Zayed et al., 2017.

\subsection{Substances effect}

Seed priming using salicylic acid produced the maximum number of tillers, panicle numbers, and filled grains as well as panicles length in both seasons. The treatment of salicylic spray gave the heaviest panicles and 1000-grain weight without significant differences with the rest of treatments, except of yeast and bacteria seed priming treatments in both seasons. The control treatment had the lowest values of all yield traits, but the highest values of unfilled grain in the two seasons. On contrast, the seed priming in salicylic was found to be more efficient to reduce the hazard salinity effect on panicle fertility producing the lowest values of unfilled grains number hill $^{-1}$ in both seasons. Similar findings were obtained by Mohamed et al., 2015 and Gharib et al., 2011.

Table (9): Plant height (cm), number of tillers hill $^{-1}$, number of panicles hill ${ }^{-1}$, of some rice varieties as affected by some substances under saline soil

\begin{tabular}{|c|c|c|c|c|c|c|}
\hline \multirow[t]{2}{*}{ Treatment } & \multicolumn{2}{|c|}{ Plant height( $\mathrm{cm})$} & \multicolumn{2}{|c|}{ No. of tillers hill ${ }^{-1}$} & \multicolumn{2}{|c|}{ No. of panicles hill } \\
\hline & 2015 & 2016 & 2015 & 2016 & 2015 & 2016 \\
\hline \multicolumn{7}{|l|}{ Varieties } \\
\hline Giza177 & $82.84 c$ & $82.73 c$ & $14.65 \mathrm{c}$ & $12.63 \mathrm{c}$ & $12.53 \mathrm{c}$ & $11.17 \mathrm{c}$ \\
\hline Giza179 & $98.67 b$ & 98.48b & $23.82 \mathrm{~b}$ & $25.20 \mathrm{~b}$ & $20.67 b$ & $22.63 b$ \\
\hline Egyptian hyprid1 & $101.1 \mathrm{a}$ & $100.9 a$ & $25.99 a$ & $27.33 a$ & $23.43 a$ & $24.76 a$ \\
\hline$F$ test & ** & $\star *$ & $* *$ & ** & $* *$ & ** \\
\hline \multicolumn{7}{|l|}{ Substances } \\
\hline Control & $89.14 c$ & $89.20 c$ & $20.20 f$ & $20.85 \mathrm{e}$ & $16.67 \mathrm{e}$ & $18.70 \mathrm{e}$ \\
\hline Salicylic soaking & $96.76 a$ & $96.42 a$ & $22.75 a$ & $23.54 a$ & $20.48 a$ & $21.26 a$ \\
\hline Bacteria soaking & $92.92 b$ & $93.09 b$ & $21.44 \mathrm{~cd}$ & $21.90 \mathrm{c}$ & $19.08 \mathrm{bc}$ & $19.77 \mathrm{c}$ \\
\hline Yeast soaking & $92.65 \mathrm{~b}$ & $92.65 \mathrm{~b}$ & 21.21de & $21.69 \mathrm{~cd}$ & $18.83 \mathrm{c}$ & $19.10 d$ \\
\hline Salicylic spray & $97.75 a$ & $97.78 \mathrm{a}$ & 22.25ab & $22.15 b$ & $19.66 \mathrm{~b}$ & $20.06 b$ \\
\hline Yeast spray & 93.95b & $93.40 \mathrm{~b}$ & $21.36 \mathrm{~d}$ & $21.32 d$ & $18.86 \mathrm{c}$ & $19.20 \mathrm{~d}$ \\
\hline Bacteria spray & $97.75 a$ & $96.72 a$ & $22.03 b c$ & $21.27 d$ & $18.97 b c$ & 19.19d \\
\hline F test & ** & ** & ** & ** & ** & ** \\
\hline Interaction & ** & ** & ** & ** & ** & ** \\
\hline
\end{tabular}

* and ${ }^{* *}$ indicate $P<0.05, P<0.01$, respectively. Means of each factor designated by the same latter are not significantly different at $5 \%$ level using Duncan's Multiple Range Test. 
5.3. The interaction effect:

The interaction effects between rice varieties and tested substances had significant effects on plant height, number of tillers, number of panicles, number of filled grains and 1000-grain weight in 2015 and 2016 seasons Tables $(10,11,14$, and 15$)$. The highest values of plant height, tillers number, panicle number were obtained by Egyptian hybrid one (EHR1) under seed soaking in salicylic acid in both seasons. Both of foliar spray and seed soaking in substances with tested varieties were improved filled grain.

Table 10: Plant height $(\mathrm{cm})$ as affected by interaction between rice varieties and different substances

\begin{tabular}{|c|c|c|c|c|c|c|}
\hline \multirow[t]{2}{*}{ substances } & \multicolumn{3}{|c|}{2015} & \multicolumn{3}{|c|}{2016} \\
\hline & Giza 177 & Giza 179 & EHRI & Giza 177 & Giza 179 & EHRI \\
\hline Control & $75.33 i$ & 95.1c-f & 97.0b-f & $75.50 \mathrm{i}$ & 95.1ef & 97.01def \\
\hline Salicylic soaking & 82.0h & $101.5 a b c$ & $106.7 a$ & $81.83 \mathrm{~h}$ & $101.4 a-d$ & $106.0 \mathrm{a}$ \\
\hline Bacteria soaking & $82.66 \mathrm{~h}$ & 99.86a-d & 96.23b-f & 83.33gh & $99.53 \mathrm{~b}-\mathrm{e}$ & 96.41def \\
\hline Yeast soaking & $83.66 \mathrm{~h}$ & 93.43def & $100.8 \mathrm{abc}$ & 83.94gh & $93.30 f$ & 100.7a-e \\
\hline Salicylic spray & $86.00 \mathrm{gh}$ & $101.4 \mathrm{abc}$ & $105.8 \mathrm{a}$ & 86.33gh & $101.3 a-d$ & $105.6 a b$ \\
\hline Yeast spray & $86.00 \mathrm{gh}$ & 93.00def & $102.8 \mathrm{ab}$ & $85.00 \mathrm{gh}$ & $92.83 f$ & $102.3 a-d$ \\
\hline Bacteria spray & $90.76 \mathrm{fg}$ & 103.6ab & $97.80 \mathrm{~b}-\mathrm{e}$ & $88.26 \mathrm{~g}$ & 103.5abc & $98.33 c-f$ \\
\hline
\end{tabular}

Table 11: Tillers and panicle number as affected by interaction between rice varieties and different substances

\begin{tabular}{|c|c|c|c|c|c|c|}
\hline \multirow{3}{*}{ Substance } & \multicolumn{3}{|c|}{ 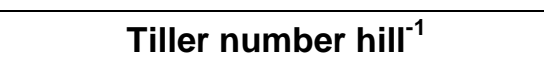 } & \multicolumn{3}{|c|}{ Panicle number hill $^{-1}$} \\
\hline & \multicolumn{6}{|c|}{2015} \\
\hline & Giza 177 & Giza 179 & EHYI & Giza 177 & Giza 179 & EHYI \\
\hline Control & $12.63 i$ & 23.26de & $24.70 b$ & $10.46 \mathrm{~h}$ & $17.46 f$ & $22.10 \mathrm{bc}$ \\
\hline Salicylic soaking & $14.06 \mathrm{~h}$ & $25.76 b$ & $28.43 a$ & $12.13 \mathrm{~g}$ & $23.16 \mathrm{~b}$ & $26.16 a$ \\
\hline Bacteria soaking & $14.86 \mathrm{gh}$ & $23.70 \mathrm{cde}$ & $25.76 b$ & $12.96 \mathrm{~g}$ & $21.10 \mathrm{bc}$ & $23.19 b$ \\
\hline Yeast soaking & $14.93 \mathrm{gh}$ & $23.26 \mathrm{de}$ & $25.43 b$ & $13.00 \mathrm{~g}$ & $20.66 \mathrm{cde}$ & $22.85 b$ \\
\hline Salicylic spray & $15.38 \mathrm{gh}$ & $24.93 b c$ & $26.43 b$ & $12.83 \mathrm{~g}$ & $22.33 b c$ & $23.83 b$ \\
\hline Yeast spray & $15.73 \mathrm{~g}$ & $22.96 \mathrm{e}$ & $25.40 \mathrm{~b}$ & $13.43 \mathrm{~g}$ & 20.36de & $22.80 \mathrm{~b}$ \\
\hline \multirow{2}{*}{ Bacteria spray } & $17.13 f$ & $23.50 \mathrm{cde}$ & $25.46 b$ & $13.16 \mathrm{~g}$ & $20.90 \mathrm{cde}$ & $22.86 \mathrm{~b}$ \\
\hline & \multicolumn{6}{|c|}{2016} \\
\hline Control & $11.67 \mathrm{~h}$ & $24.72 d$ & $26.16 \mathrm{c}$ & $10.37 \mathrm{~g}$ & 22.15d & $23.59 \mathrm{c}$ \\
\hline Salicylic soaking & $13.51 f$ & $27.22 \mathrm{bc}$ & $29.89 a$ & $11.81 f$ & $24.65 b c$ & $27.32 a$ \\
\hline Bacteria soaking & $13.30 \mathrm{fg}$ & $25.16 d$ & $27.25 b c$ & $12.05 \mathrm{e}$ & 22.59d & $24.68 \mathrm{bc}$ \\
\hline Yeast soaking & $13.46 f$ & 24.72d & 26.91bc & $10.83 \mathrm{fg}$ & 22.15d & $24.34 \mathrm{bc}$ \\
\hline Salicylic spray & $12.19 \mathrm{gh}$ & $26.39 c$ & $27.89 b$ & $11.06 \mathrm{fg}$ & $23.82 \mathrm{c}$ & $25.32 b$ \\
\hline Yeast spray & 12.70fgh & $24.42 d$ & $26.86 b c$ & $11.46 \mathrm{fg}$ & $21.85 \mathrm{c}$ & $24.29 \mathrm{c}$ \\
\hline Bacteria spray & $12.62 \mathrm{gh}$ & $24.29 d$ & $26.92 b c$ & $11.05 \mathrm{~g}$ & $21.72 d$ & $24.35 b c$ \\
\hline
\end{tabular}


Amira M. Okasha

Table (12): Panicle length, panicle weight of some rice varieties as affected by some substances under saline soil in 2015 and 2016 seasons

\begin{tabular}{|c|c|c|c|c|}
\hline \multirow[t]{2}{*}{ Treatment } & \multicolumn{2}{|c|}{ Panicle length(cm) } & \multicolumn{2}{|c|}{ Panicle weight(g) } \\
\hline & 2015 & 2016 & 2015 & 2016 \\
\hline \multicolumn{5}{|l|}{ Variety } \\
\hline Giza177 & $18.98 b$ & $19.70 b$ & $2.34 \mathrm{c}$ & $2.23 \mathrm{c}$ \\
\hline Giza179 & $18.45 b$ & $19.95 b$ & $2.71 b$ & $2.64 b$ \\
\hline EHR1 & $20.99 a$ & $22.75 a$ & $3.07 a$ & $3.04 a$ \\
\hline F test & ** & * & * & ** \\
\hline \multicolumn{5}{|l|}{ Substances } \\
\hline Control & $17.94 \mathrm{c}$ & 19.40 & $2.37 c$ & $2.27 c$ \\
\hline Salicylic soaking & $20.49 a$ & 22.20 & $2.77 a b$ & 2.71ak \\
\hline Bacteria soaking & $18.7 \mathrm{bc}$ & 20.31 & 2.73ab & $2.67 \mathrm{ab}$ \\
\hline Yeast soaking & $18.13 \mathrm{c}$ & 19.61 & $2.63 b$ & $2.55 b$ \\
\hline Salicylic spray & $20.64 a$ & 22.37 & $2.97 a$ & $2.93 a$ \\
\hline Yeast spray & $19.8 \mathrm{ab}$ & 21.52 & $2.88 a$ & $2.83 a$ \\
\hline Bacteria spray & $20.10 a$ & 19.52 & $2.75 a b$ & $2.68 \mathrm{ab}$ \\
\hline$F$ test & ** & NS & ** & ** \\
\hline Interaction & NS & NS & NS & NS \\
\hline
\end{tabular}

${ }^{*}, * *$ and Ns indicate $P<0.05, P<0.01$ and not significant, respectively. Means of each factor designated by the same latter are not significantly different at $5 \%$ level using Duncan's Multiple Range Test.

Table (13): Number of filled grains panicle ${ }^{-1}$, number of unfilled grains panicle ${ }^{-1}$ and $1000-$ grain weight $(\mathrm{g})$ of some rice varieties as affected by some substances under saline soil

\begin{tabular}{|c|c|c|c|c|c|c|}
\hline \multirow[t]{2}{*}{ Treatment } & \multicolumn{2}{|c|}{ Number of filled grains } & \multicolumn{2}{|c|}{ Number of unfilled grains } & \multicolumn{2}{|c|}{ 1000-grain weight(g) } \\
\hline & 2015 & 2016 & 2015 & 2016 & 2015 & 2016 \\
\hline \multicolumn{7}{|l|}{ Variety } \\
\hline Giza177 & 92.14c & 94.77c & $26.78 a$ & $30.99 a$ & $24.51 a$ & $24.09 a$ \\
\hline Giza179 & 117.1b & $118.9 b$ & $19.77 \mathrm{c}$ & $17.25 c$ & $22.36 b$ & $22.17 c$ \\
\hline EHR1 & $121.3 a$ & $123.6 a$ & $25.03 b$ & $27.10 b$ & $23.09 b$ & $22.85 b$ \\
\hline F test & ** & ** & ** & * & * & * \\
\hline \multicolumn{7}{|l|}{ Substances } \\
\hline Control & 98.85d & 98.53f & $32.33 a$ & $31.13 a$ & $22.22 d$ & $21.98 \mathrm{e}$ \\
\hline Salicylic soaking & $117.6 a$ & $119.1 \mathrm{a}$ & $19.02 d$ & $17.51 \mathrm{~d}$ & 23.5abc & 23.37abc \\
\hline Bacteria soaking & $112.2 b$ & $115.7 \mathrm{bc}$ & $23.33 b$ & $24.49 b$ & $23.08 \mathrm{bcd}$ & $22.73 \mathrm{~cd}$ \\
\hline Yeast soaking & 111.0b & $112.3 d$ & $22.22 c$ & $24.73 b$ & $22.95 \mathrm{~cd}$ & 22.93bcd \\
\hline Salicylic spray & $115.3 a$ & $116.3 b$ & $21.33 \mathrm{bc}$ & $24.8 b$ & $24.11 a$ & $23.87 a$ \\
\hline Yeast spray & 111.5b & $113.2 \mathrm{~cd}$ & $21.07 \mathrm{~cd}$ & $24.53 b$ & 23.93ab & 23.54ab \\
\hline Bacteria spray & $111.5 b$ & $110.5 d$ & $20.83 \mathrm{~cd}$ & $24.28 c$ & 23.84abc & 23.27abc \\
\hline F test & ** & ** & * & ** & ** & ** \\
\hline Interaction & ** & ** & NS & NS & ** & ** \\
\hline
\end{tabular}

${ }^{*}, * *$ and Ns indicate $\mathrm{P}<0.05, \mathrm{P}<0.01$ and not significant, respectively. Means of each factor designated by the same latter are not significantly different at $5 \%$ level using Duncan's Multiple Range Test. 
Table 14: Number of filled grains as affected by interaction between rice varieties and different substances in 2015 and 2016 seasons

\begin{tabular}{|l|l|c|c|c|c|c|}
\hline \multirow{2}{*}{ Substance } & \multicolumn{3}{|c|}{2015} & \multicolumn{3}{c|}{2016} \\
\cline { 2 - 7 } & Giza 177 & Giza 179 & EHRI & Giza 177 & Giza 179 & EHRI \\
\hline Control & $80.66 \mathrm{k}$ & $103.6 \mathrm{ef}$ & $112.2 \mathrm{~d}$ & $\mathbf{8 4 . 4 3 \mathrm { h }}$ & $104.2 \mathrm{de}$ & $113.6 \mathrm{c}$ \\
\hline Salicylic soaking & $100.6 \mathrm{efg}$ & $124.5 \mathrm{ab}$ & $127.6 \mathrm{a}$ & $105.4 \mathrm{~d}$ & $127.2 \mathrm{a}$ & $130.6 \mathrm{a}$ \\
\hline Bacteria soaking & $\mathbf{8 9 . 6 6 \mathrm { ij }}$ & $122.1 \mathrm{ab}$ & $124.9 \mathrm{ab}$ & $96.20 \mathrm{efg}$ & $124.5 \mathrm{ab}$ & $127.5 \mathrm{a}$ \\
\hline Yeast soaking & $\mathbf{9 7 . 2 3 \mathrm { fgh }}$ & $114.0 \mathrm{~cd}$ & $121.9 \mathrm{ab}$ & $97.15 \mathrm{ef}$ & $115.6 \mathrm{bc}$ & $124.3 \mathrm{ab}$ \\
\hline Salicylic spray & $\mathbf{9 7 . 3 3 f g h}$ & $122.7 \mathrm{ab}$ & $125.9 \mathrm{ab}$ & $97.26 \mathrm{ef}$ & $125.2 \mathrm{ab}$ & $128.6 \mathrm{a}$ \\
\hline Yeast spray & $\mathbf{9 4 . 5 0 \mathrm { ghi }}$ & $121.6 \mathrm{ab}$ & $118.5 \mathrm{de}$ & $95.98 \mathrm{efg}$ & $124.0 \mathrm{ab}$ & $120.6 \mathrm{abc}$ \\
\hline Bacteria spray & $\mathbf{9 2 . 5 0 \mathrm { hi }}$ & $122.3 \mathrm{ab}$ & $119.6 \mathrm{~cd}$ & $\mathbf{8 8 . 2 8 f g}$ & $124.7 \mathrm{ab}$ & $121.8 \mathrm{abc}$ \\
\hline
\end{tabular}

Table 15: 1000-grain weight as affected by interaction between rice varieties and different substances in 2015 and 2016 seasons

\begin{tabular}{|l|l|l|l|c|c|c|}
\hline \multirow{2}{*}{ substances } & \multicolumn{3}{|c|}{2015} & \multicolumn{3}{c|}{2016} \\
\cline { 2 - 7 } & Giza 177 & Giza 179 & EHRI & Giza 177 & Giza 179 & EHRI \\
\hline Control & $22.83 c d e$ & $21.23 e$ & $22.6 c d e$ & $22.59 d e f$ & $20.99 f$ & $22.36 d e f$ \\
\hline Salicylic soaking & $23.63 b-e$ & $22.76 c d e$ & $24.1 b c d$ & $23.72 b c d$ & $22.52 d e f$ & $23.86 a-d$ \\
\hline Bacteria soaking & 25.1 abc & $21.53 d e$ & $22.63 c d e$ & $24.52 a b c$ & 21.29 ef & $22.39 d f$ \\
\hline Yeast soaking & $23.83 b c d$ & $22.6 c d e$ & $22.43 d e$ & $23.92 a-d$ & $22.69 d e f$ & $22.19 d e f$ \\
\hline Salicylic spray & 25.1 abc & $23.163 b-e$ & $24.13 b c d$ & $24.86 a b$ & $22.86 c-f$ & $23.89 a-d$ \\
\hline Yeast spray & $25.43 a b$ & $22.88 c d e$ & $23.563 b-e$ & $24.74 a b$ & $22.64 d e f$ & $23.26 b c d$ \\
\hline Bacteria spray & $26.66 a$ & $22.4 d e$ & $22.46 d e$ & $25.42 a$ & $22.16 d e f$ & $22.22 d e f$ \\
\hline
\end{tabular}

The highest values of filled grains were produced by the combination of EHR1 and seed soaking in salicylic acid. Filled grains increased in tested rice varieties as a result of seed priming by salicylic acid or its spray, as well as using bacteria and yeast extract may be due to alleviation of salinity harmful effect on panicle fertility.

\section{Yields}

\subsection{Rice varieties performance}

Rice varieties markedly differed grain yield biological yield and harvest index in both seasons Table (16). The greatest grain was yielded by Egyptian hybrid one followed by Giza179, but Giza177 came in the last order regarding grain yield. As for biological yield Egyptian hybrid one was the best followed by Giza179 in the first season and Giza177 in the second season. Meanwhile, Egyptian hybrid one produced the highest value of harvest index without differ with Giza179 in the second season. EHR1 kept its superiority whereas, it gave the higher grain yield comparing to the two inbred rice varieties owing to its high heterosis and salinity withstanding, Interestingly, Giza179 inbred rice variety came in the second rank after EHR1 regarding the grain yield and salinity tolerance. The yield results of the two previous mentioned varieties were tightly matching with their growth performance and yield attributes as well as their low $\mathrm{Na}^{+} / \mathrm{K}^{+}$ratio. Giza177 rice variety possessed low yield as a result of low yield attributed, bad growth behavior and poor ion selectivity in the terms of high $\mathrm{Na}^{+} / \mathrm{K}^{+}$ratio. Zayed et al., 2017 ratified the similar trend. 
Table (16): Yield $\left(\mathrm{t} \mathrm{ha}^{-1}\right)$ and harvest index of some rice varieties as affected by some substances under saline soil

\begin{tabular}{|c|c|c|c|c|c|c|}
\hline \multirow[t]{2}{*}{ Treatment } & \multicolumn{2}{|c|}{ Grain yield(t ha $\left.{ }^{-1}\right)$} & \multicolumn{2}{|c|}{ Biological yield(t ha $\left.{ }^{-1}\right)$} & \multicolumn{2}{|c|}{ Harvest index } \\
\hline & 2015 & 2016 & 2015 & 2016 & 2015 & 2016 \\
\hline \multicolumn{7}{|l|}{ Variety } \\
\hline Giza177 & $2.09 c$ & $1.94 \mathrm{c}$ & $6.54 c$ & $6.52 b$ & $0.21 \mathrm{c}$ & $0.29 b$ \\
\hline Giza179 & $3.01 b$ & $2.90 \mathrm{~b}$ & $7.59 b$ & $7.67 \mathrm{c}$ & $0.30 \mathrm{~b}$ & $0.38 a$ \\
\hline EHY1 & $3.88 a$ & $3.70 a$ & $9.30 a$ & $9.48 a$ & $0.39 a$ & $0.40 a$ \\
\hline F test & ** & $* *$ & ** & $* *$ & $* *$ & ** \\
\hline \multicolumn{7}{|l|}{ Substance } \\
\hline control & 2.49de & $2.37 \mathrm{e}$ & $7.01 \mathrm{c}$ & $6.90 \mathrm{c}$ & $0.25 d$ & $0.33 b$ \\
\hline Salicylic soaking & $3.60 \mathrm{a}$ & $3.56 a$ & 8.34ab & $8.50 a$ & $0.36 a$ & $0.40 a$ \\
\hline Bacteria soaking & $2.72 \mathrm{~cd}$ & $2.80 \mathrm{~cd}$ & $7.23 \mathrm{c}$ & $7.49 \mathrm{bc}$ & $0.27 c$ & $0.37 a b$ \\
\hline Yeast soaking & $2.78 \mathrm{c}$ & $2.65 d$ & $7.61 b c$ & $7.52 \mathrm{bc}$ & $0.27 \mathrm{c}$ & $0.35 b$ \\
\hline Salicylic spray & $3.34 \mathrm{~b}$ & $3.25 a$ & $8.64 a$ & $8.86 a$ & $0.33 b$ & $0.35 b$ \\
\hline Yeast spray & $3.30 \mathrm{~b}$ & $3.14 b$ & 8.35ab & $8.37 a b$ & $0.33 b$ & $0.37 a b$ \\
\hline Bacteria spray & $3.25 b$ & $2.96 \mathrm{bc}$ & $8.57 a$ & $8.73 a$ & $0.32 b$ & $0.33 b$ \\
\hline F test & ** & ** & ** & ** & $* *$ & ** \\
\hline Interaction & ** & ** & NS & NS & NS & NS \\
\hline
\end{tabular}

${ }^{*},{ }^{*}$ and $N s$ indicate $P<0.05, P<0.01$ and not significant, respectively. Means of each factor designated by the same latter are not significantly different at $5 \%$ level using Duncan's Multiple Range Test.

\subsection{Effect of substances}

Grain and biological yields, and harvest index of rice significantly and positively affected by varying substances seed soaking and foliar spray treatments in both seasons (Table16). The impact of salicylic acid either soaking or foliar spray had high beneficial concerning grain and biological yields. The highest grain and biological yields were obtained by salicylic soaking compared with control treatment. Salicylic foliar spray significantly increased biological yield without significant difference with salicylic and bacteria foliar spray in both seasons Harvest index was increased by salicylic soaking in both seasons. The increase in grain yield by salicylic acid and bacteria may be due to germination improvement and early growth which reflected on higher yield attributes (number of panicle, panicle weight, number of filled grains and 1000-grain weight) and in turn increased grain yield.
Also the mentioned substances had positive role in raising rice salinity tolerance by minimizing the $\mathrm{Na}^{+}$uptake magnifying $\mathrm{K}^{+}$uptake resulted in low $\mathrm{Na}^{+} / \mathrm{K}^{+}$ratio. (Mohamed et al., 2015) has been reported the similar pattern.

\subsection{The interaction effect}

The interaction between rice varieties and substances had a significant on grain yield in both seasons (Table 17). The interaction effect of grain yield result came to fix that all tested substances improved grain yield of the tested rice varieties. Furthermore, the results of grain yield interaction confirmed higher efficiency of salicylic acid treatment either seed priming or foliage spray in improving rice yield under salt stress as a results of raising rice salinity tolerance. The highest values of grain yield was obtained by Egyptian hybrid one when it was soaked in salicylic solution in both seasons. 
Table 17: Grain yield $\mathrm{t} \mathrm{ha} \mathrm{h}^{-1}$ as affected by interaction between rice varieties and different substances in 2015 and 2016 seasons

\begin{tabular}{|l|c|c|c|c|c|c|}
\hline \multirow{2}{*}{ Substance } & Giza177 & Giza 179 & EHR1 & Giza 177 & Giza 179 & EHR1 \\
\cline { 2 - 7 } & \multicolumn{5}{|c|}{2015} & \multicolumn{3}{c|}{2016} \\
\hline control & $1.63 \mathrm{~h}$ & $2.33 \mathrm{fg}$ & $3.51 \mathrm{c}$ & $1.49 \mathrm{~h}$ & $2.20 \mathrm{e}-\mathrm{h}$ & $3.42 \mathrm{bc}$ \\
\hline Salicylic soaking & $1.93 \mathrm{gh}$ & $3.85 \mathrm{bc}$ & $5.01 \mathrm{a}$ & $1.94 \mathrm{fgh}$ & $3.77 \mathrm{c}$ & $4.99 \mathrm{a}$ \\
\hline Bacteria soaking & $1.74 \mathrm{~h}$ & $2.68 \mathrm{ef}$ & $3.73 \mathrm{bc}$ & $2.20 \mathrm{e}-\mathrm{h}$ & $2.56 \mathrm{def}$ & $3.65 \mathrm{bc}$ \\
\hline Yeast soaking & $1.93 \mathrm{gh}$ & $2.81 \mathrm{ef}$ & $3.60 \mathrm{bc}$ & $1.76 \mathrm{gh}$ & $2.69 \mathrm{de}$ & $3.51 \mathrm{bc}$ \\
\hline Salicylic spray & $2.40 \mathrm{fg}$ & $3.45 \mathrm{~cd}$ & $4.18 \mathrm{~b}$ & $2.11 \mathrm{e}-\mathrm{h}$ & $3.36 \mathrm{bc}$ & $4.12 \mathrm{~b}$ \\
\hline Yeast spray & $2.53 \mathrm{fg}$ & $3.21 \mathrm{cde}$ & $4.16 \mathrm{~b}$ & $2.22 \mathrm{e}-\mathrm{h}$ & $3.11 \mathrm{~cd}$ & $4.10 \mathrm{~b}$ \\
\hline Bacteria spray & $2.88 \mathrm{def}$ & $3.26 \mathrm{cde}$ & $3.61 \mathrm{bc}$ & $2.20 \mathrm{e}-\mathrm{h}$ & $3.16 \mathrm{~cd}$ & $3.53 \mathrm{bc}$ \\
\hline
\end{tabular}

In summary, rice seed priming or plant foliar spray with extraction of salicylic acid or bacteria more efficient than yeast, they are beneficial in improving growth and yield of rice varieties under the harmful effect of salinity.

\section{REFERENCES}

Afzal, I., M. Shahzad, B.N. Ahmad and M.F. Ahmad (2005). Optimization of hormonal priming techniques for alleviation of salinity stress in wheat (Triticum aestivumL.). Caderno de Pesquisa Sér. Bio. Santa Cruz do Sul., 17:95-109.

Alam, M.M., M. Hasanuzzaman and K. Nahar (2009). Tiller dynamics of three irrigated rice varieties under varying phosphorus levels. Amer. J. of Agron., 2(2):89-94.

Anil, V.S., H. Krishnamurthy and M.K. Mathew (2007). "Limiting cytosolic $\mathrm{Na}^{+}$ confers salt tolerance to rice cells in culture: a two-photon microscopy study of SBFI-loaded cells", Physiologia Plantarum, 129 (3): 607621.

Babalola, O.O. and B.R. Glick (2012). The use of microbial inoculants in African agriculture: current practice and future prospects. J Food Agri Environ, 10(3-4):540-549

Bam, R. K., F. K. Kumaga, K. Ori and E.A. Asiedu (2006). Germination, vigour and dehydrogenase activity of naturally aged rice (Oryza sativa L.) seeds soaked in potassium and phosphorus Asian Journal of Plant Sciences, 5(6): 948-955.

Barkosky, R.R. and F.A. Einhellig (1993). Effects of salicylic acid on plant water relationship. J. Chem. Eco., 19: 237247.

Bashan, Y. and LE De-Bashan (2010). How the plant growth-promoting bacterium Azospirillum pro- motes plant growth a critical assessment. Adv Agron, 108:77-136

Bashan, Y. and G. Holguin (1998). Proposal for the division of plant growth-promoting Rhizobacteria into two classifications: biocontrol-PGPB (plant growth-promoting bacteria) and PGPB. Soil Biol Biochem ,30:12251228

Basra, S.M.A., M. Farooq, I. Afzal and M. Hussain (2006). Influence of osmopriming on the germination and early seedling growth of coarse and fine rice. Inter. J. Agric. Biol., 8: 1922.

Black, C.A. (1965). Methods of soil analysis part II. Amer. Soc. Agro. Madison, Wisconsin, USA.

Chapman, H.D. and P.E. Pratt (1978). Methods of Analysis for Soils, Plants and Waters. Univ. of Calif., Div. Agric. Sci Priced Pub., 4034. pp: 50-169.

Cutt, J.R. and D.F. Klessing (1992). Salicylic acid in plants. A changing 
perspective. J. Pharm. Sci. Tech., 16: 25-34.

Darweesh, M. A., E. A. Tartoura and K. Dawa (2003). Effect of phosphorous fertilization and some growth promoters on growth and yield of pea.J. Agric. Sci. Mans. Univ. Egypt, 28 (12): 1327-1343.

Duncan, B. D. (1995). Multiple ranges and multiple F-tests. Biometrics, 11:42.

El-Hedek, K. S. (2013). Effect of foliar applications of salicylic acid and potassium silicate on tolerance of wheat plants to soil salinity J. Soil Sci. and Agric. Eng., Mansoura Univ., Vol. 4 (3): 335 - 357

Gharib, H. S., T.F. Metwally, S.S. Naeem and E.E. Gewaily (2011). Influence of some stimulating compounds and nitrogen fertilizer levels on growth and yield of hybrid rice Zagazig J. Agric. Res., Vol.38 No. (1):1-21

Glick, B.R. (2014). Bacteria with ACC deaminase can promote plant growth and help to feed the world. Microbiol Res 169(1):30-39.

Gomes, K. A. and A.A. Gomes (1984). Statistical Procedures for Agricultural Research, International Rice Research Institute. 2nd ED. John Wily and Sons, New York, US

Hosseini, M.K., A.A. Powell and I.J. Bingham (2003). The interaction between salinity stress and seed vigor during germination of soybean seeds. Seed Sci. Technol., 31:715-725.

Hussein, M.M., L.K. Balbaa and M.S. Gaballah (2007). Salicylic acid and salinity effects on growth of maize plants. Res.J. Agric. and Biological Sci,.3:321-328.

Iqbal, M. and M. Ashraf (2010). Changes in hormonal balance: $A$ possible mechanism of pre-sowing chillinginduced salt tolerance in spring wheat. J. Agron. Crop Sci., 196: 440454.

IRRI, (2011). Measuring Seed Germination. Post-Harvest Fact
Sheets.

Retrieved from:http://www.knowledgebank.irri.or g/factsheetsPDFs/CropEstabl ishment_Measuring\%20Seed\%20Germ ination.pdf.

Islam, R., A. Mukherjee and M. Hossin (2012). Effect of osmopriming on rice seed germination and seedling growth. J. Bangladesh Agric.Univ.,10(1):15-20

Kandil, A.A., A.E. Sharief and E.S.E. Nasser (2012). Responce of some rice (oriza sativa $L$ ) cutivars to germination under salinity stress. International Jornal of Agriculture Sciences, 4(6):272-277.

Karan, R., T. DeLeon, H. Biradar and P.K. Subudhi (2012). "Salt stress induced variation in DNA methylation pattern and its influence on gene expression in contrasting rice genotypes", PLoS One, 7(6):40203

Kishk, A.M.A. (2006). Effect of different irrigation and organic fertilizer treatments on yield and technological characteristics of some rice cultivars, M.Sc. Thesis, Agron. Dept., Fac. of Agric., Mansoura univ., Egypt, Pp 123

kouio, A.G. (2003). Chemical and biological changes in seed treatment of rice varieties. Journal of rice Science. International Rice Research Institute, Los Banos, Philippines, pp 207-215.

Krishnaswamy, V. and D.V. Seshu (1990). Germination after accelerate aging and associated characters in rice varieties. Seed Sci. and Tech., 18: 14715.

Lee, S. Y., J.H. Lee and T.O. Kwan (2002). Varietals differences in seed germination and seedling vigor of Korean rice varieties following dry heat treatment. Seed Sci\& Technol., 30:311-321.

Mohamed, A.A., B. A. Zayed, S.Gh.R. Sorour and Amira M. Okasha (2015). Effect of foliar spray of antioxidants on rice growth under saline soil 
condition. J. Agric. Res., Kafr ElSheikh Univ., 41(1): 52-65

Parizi, M.D., K.M. Kalantari, S. Enteshari and A. Baghizadeh (2011). Effect of salicylic acid and salt stress on $\mathrm{Na}$ and $K$ content in ocimum basillicum L., Iranian J.Plant Physiology.3:133139.

Rafique, N., H. Raza, M. Qasim and N. Iqbal (2011). Pre-sowing application of ascorbic acid and salicylic acid to seed of pumpkin and seedling response to salt. Pak. J. Bot., 43: 2677-2682.

Sairam, R.K, K.V. Rao and G.C. Srivastava (2002). Differential response of wheat genotypes to long term salinity stress in relation to oxidative stress, antioxidant activity and osmolyte concentration", Journal of Plant Science, Vol. 163, pp. 10371046.

Sakhabutdinova, A.R., $\quad$ D.R. Fatkhutdinova, M.V. Bezrukova and F.M. Shakirova (2003). Salicylic acid prevents the damaging action of stress factor in wheat plants. Bulg. J. Plant Physiol., Special Issue: 314-319.
Situation Analysis Taskforce (SIT), (2010). Situation Analysis: Key Development Challenges FacingEgypt.[online]pp.88--

96.Availableat://www.un.org.eg/docs/1 01100\%20SA\%20

httpReport\%20final\%20pdf\%20version .pdf[Accessed10 Aug. 2015].

Trutneva, K.A. and V.E Nikitina (2014). Signal effects of the lectin from the associative nitrogen-fixing bacterium Azospirillum brasilense $\mathrm{Sp} 7$ in bacterial-plant root interactions. Plant Soi, 381(1-2):337-349

Zayed, A.B., W.M. El-Khoby, S.M. Shehata and M.H. Ammar (2007). Role of potassium application on productivity of some inbred and hybrid rice varieties under newly reclaimed saline soil. 8th African Crop Science Society Conferences, 27-31 October. 2007-EI Minia, Egypt vol (1) pp, 53-60.

Zayed, B.A., Rania Khedr, A.A Hadifa and Amira M. Okasha (2017). Some antioxidants phsysio- morphological and yield of varying rice varieties affected by salinity levels. Mansoura Univ.,8 (7) :747-754. 
دور معامله البذور والرش باستخدام بعض المواد الحيوية وإلكيماوية في زيادة تحمل

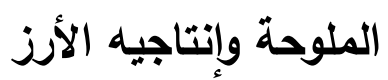

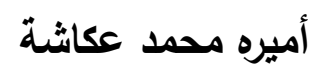 \\ قسم بحوث الأزز - معهد بحوث المحاصيل الحقلية - مركز البحوث الزراعية - سخا - كفر الثيخ - مصر مر \\ الملخص العربي
}

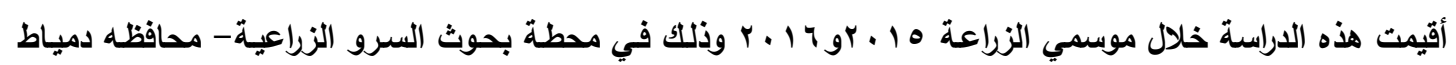

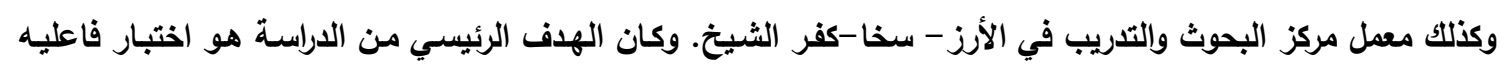

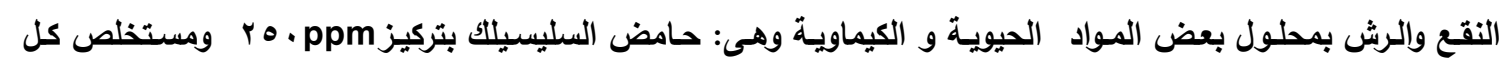
الخميرة r كجم/فدان والبكتريا بتركيز r\% و وذلك خلال مراحل نمو الأرز المختلفة (متوسط التفريع +بداية تكوين السنبلة

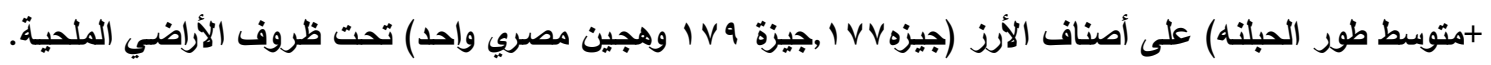

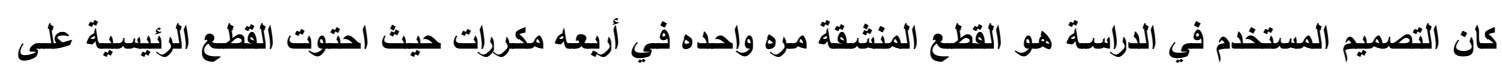

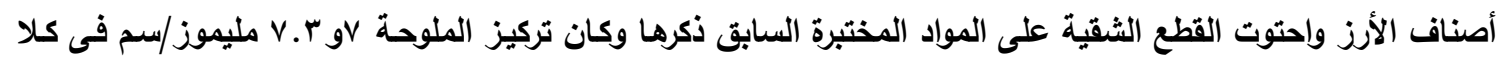

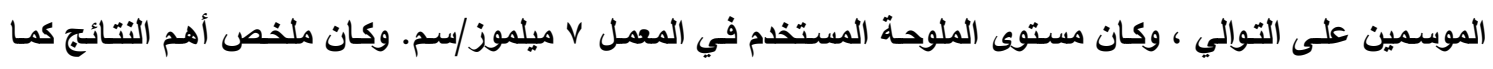

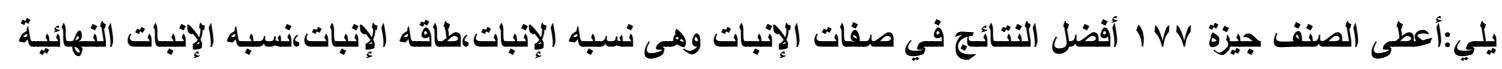

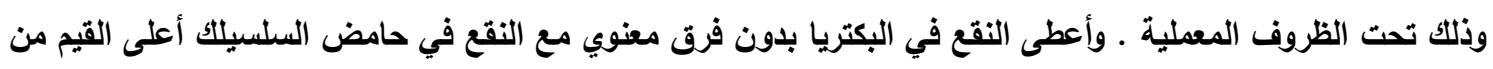

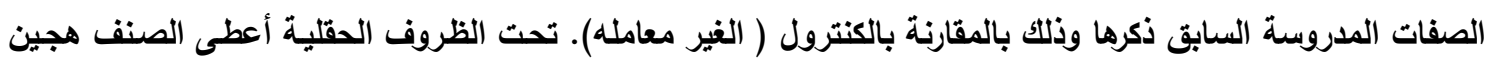

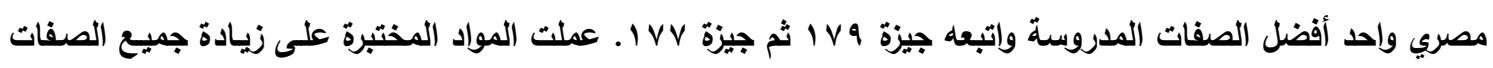

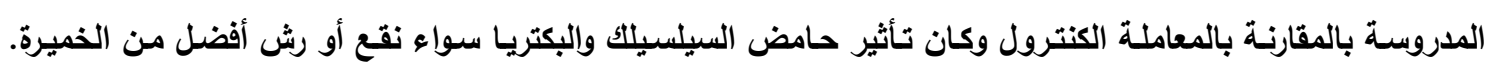

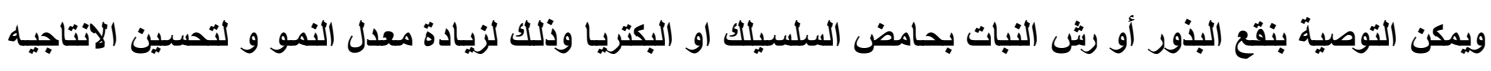
لنبات الأرز المنزرع تحت ظروف الاراضى الملحية.

أسماء السادة المحكمين

مركز بحوث الأرز - كفر الثيخ

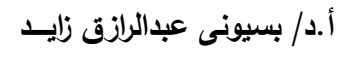

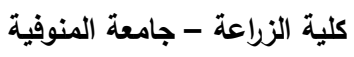
أ.د / محمود الاسوقى إبراهيم 
Role of seed priming and spraying some bio and chemical substances ....... 